Article

\title{
Carbon and Nitrogen Dynamics Affected by Drip Irrigation Methods and Fertilization Practices in a Pomegranate Orchard
}

\author{
Rebecca Tirado-Corbalá ${ }^{1, *(1)}$, Suduan Gao ${ }^{2}$, James E. Ayars ${ }^{2}$, Dong Wang ${ }^{2}$, Claude J. Phene ${ }^{3}$ \\ and Rebecca C. Phene ${ }^{4}$ \\ 1 Agro-Environmental Sciences Department, University of Puerto Rico-Mayagüez, P.O. Box 9000, Mayagüez, \\ PR 00681, USA \\ 2 USDA, Agricultural Research Service, San Joaquin Valley Agricultural Sciences Center, Parlier, CA 93648, \\ USA; suduan.gao@ars.usda.gov (S.G.); james.ayars@gmail.com (J.E.A.); dong.wang@ars.usda.gov (D.W.) \\ 3 SDI+, P.O. Box 314, Clovis, CA 93613, USA; claudejphene@gmail.com \\ 4 Kearney Agricultural Research and Extension Center, University of California, 9240 S. Riverbend Ave., \\ Parlier, CA 93648, USA; rcphene@ucanr.edu \\ * Correspondence: rebecca.tirado@upr.edu or rebeccatiradocorbala@gmail.com; Tel.: +1-787-370-9179
}

Received: 25 September 2019; Accepted: 10 December 2019; Published: 12 December 2019

\begin{abstract}
Knowledge of carbon $(\mathrm{C})$ and nitrogen $(\mathrm{N})$ dynamics under different irrigation practices in pomegranate orchards is novel and essential to develop sustainable production systems. The aim of this research was to determine the effect of high-frequency drip irrigation and different rates of $\mathrm{N}$ fertilizer on $\mathrm{C}$ and $\mathrm{N}$ distribution in the soil and $\mathrm{N}$ uptake by pomegranate fruit and leaves. The main treatments were surface drip irrigation (DI) and subsurface drip irrigation (SDI), and the sub-treatments used were three initial $\mathrm{N}$ rates $(\mathrm{N} 1, \mathrm{~N} 2$, and $\mathrm{N} 3)$. As trees grew larger, the $\mathrm{N}$ application rate increased. From 2013-2015, trees received the following rates of N: 62-113 (N1), 166-263 (N2), or 244-342 kg/ha (N3). Soil and leaf total C (TC) and N (TN), soil dissolved organic C (DOC), soil nitrate $\left(\mathrm{NO}_{3}{ }^{-}\right)$, and total $\mathrm{N}$ uptake by fruit were evaluated between 2012 and 2015. Soil samples were collected to $120 \mathrm{~cm}$ depth at $15 \mathrm{~cm}$ increments. DI resulted in higher concentrations of TN, TC, $\mathrm{NO}_{3}{ }^{-}$, and DOC in the upper $75 \mathrm{~cm}$ depth than SDI. The N3 treatment resulted in higher concentrations of TN, TC, $\mathrm{NO}_{3}{ }^{-}$, and DOC under both DI and SDI. Neither DI nor SDI at the N1 or N2 levels increased $\mathrm{TN}$ and $\mathrm{NO}_{3}{ }^{-}$concentrations at $105-120 \mathrm{~cm}$ soil depth, indicating reduced leaching risk using high-frequency drip irrigation. Higher $\mathrm{N}$ uptake by fruit was observed in SDI than in DI in 2014 and 2015, and in N2 and N3 treatments compared with N1 in 2013 and 2014. The data indicate that the application rate at $166-263 \mathrm{~kg} / \mathrm{ha}$ (N2) provided sufficient $\mathrm{N}$ for a 4-6-year-old pomegranate orchard and that high-frequency SDI is a promising technology for achieving higher $\mathrm{N}$ use efficiency and minimizing leaching loss of $\mathrm{NO}_{3}{ }^{-}$and DOC.
\end{abstract}

Keywords: dissolved organic carbon; total carbon; total nitrogen; nitrate; subsurface drip irrigation; $\mathrm{N}$ uptake

\section{Introduction}

Pomegranate (Punica granatum L.) is a deciduous fruit tree native to central Asia [1]. Its production in the United States has increased in recent years due to consumer interest in pomegranate organoleptic characteristics and beneficial effects on human health [2]. California is the top pomegranate production state in the U.S. with approximately $\$ 47$ billion production in 2015 [3,4], >99\% of all production in the United States, with 783 farms occupying a total of 13,041 ha primarily located in the Central Valley [4]. Drought has been increasingly challenging to crop production in California, and pomegranate has been 
identified as a promising specialty crop due to its high drought and salinity tolerance [5-8]. Despite being an "ancient" crop, it has been studied primarily for medicinal uses $[9,10]$ and little is known about the water and fertilizer requirements of a mature pomegranate orchard, especially under different drip irrigation methods. Water and fertilizer research on pomegranate has been conducted primarily in Mediterranean climates using furrow [11] or flood irrigation systems [12], with some drip irrigation studies in Western Asia (i.e., Fars Province, Iran) under arid and semi-arid conditions [13-15]. Several pomegranate growers in California irrigate the crop with surface drip irrigation (DI) systems $[4,16]$ with little knowledge of the actual water and fertilizer requirements.

Agriculture is one of the largest drivers of spatiotemporal changes in global $\mathrm{N}$ and $\mathrm{C}$ cycles. Under a Mediterranean climate, $100 \%$ of the crop production in the Central Valley of California is irrigated with an annual output exceeding $\$ 30$ billion [3], and approximately $40 \%-80 \%$ of the total water supply is used for this irrigation $[17,18]$. High levels of nitrate $\left(\mathrm{NO}_{3}{ }^{-}\right)$in the groundwater represent a major problem in California aquifers $[19,20]$, and irrigated agriculture is a significant source of $\mathrm{NO}_{3}{ }^{-}$pollution [21,22]. Synthetic $\mathrm{N}$ fertilizers $(54 \%)$, animal manure (33\%), and irrigation water $(8 \%)$ represent the three major sources of $\mathrm{NO}_{3}{ }^{-}$found in California groundwater [20]. Export of DOC and $\mathrm{NO}_{3}{ }^{-}$from surface to groundwater is strongly influenced by agricultural practices $[19,23]$. Chomycia et al. [24] found that water from tile drains under manure-irrigated fields, which ultimately flows into the San Joaquin River in California, contained DOC concentrations about three orders of magnitude higher than in the San Joaquin River. A better understanding of the effects of irrigation and fertilization practices on pomegranate field $\mathrm{DOC}$ and $\mathrm{NO}_{3}{ }^{-}$mobility will assist in the development of more environmentally sound management strategies.

Groundwater is the major source of drinking water for many communities in the Central Valley of California. The 2014 Groundwater Act (Sustainable Groundwater Management Act) of California made protecting groundwater quality a priority for public health by reducing $\mathrm{N}$ leaching in basins that adopt salt nutrient management. $\mathrm{N}$ that is applied to crops but not removed by harvest or lost via air emission and runoff is subject to leaching from the root zone to groundwater [25]. Options for reducing $\mathrm{NO}_{3}{ }^{-}$pollution have been identified for all sources. For croplands, where less than $40 \%$ of applied $\mathrm{N}$ is removed by crop harvest, several management practices have been suggested to reduce $\mathrm{NO}_{3}{ }^{-}$leaching to groundwater. Harter et al. [21] used efficient irrigation design and fertilization management to increase $\mathrm{N}$ use efficiency. Studies done by Ayars et al. [26] demonstrated that well-managed subsurface drip irrigation (SDI) systems can eliminate surface runoff, reduce deep percolation losses, and minimize surface water evaporation for annual crops. A recent study by Baram et al. [27] estimated leaching loss of 80-240 kg N/ha y from an almond (Prunus dulcis) orchard irrigated with micro-sprinklers, and most of the loss occurred early in the growing season (February-May), when urea-ammonium nitrate fertilizer was commonly applied to wet soil. Thus, high-frequency DI and fertigation could potentially reduce fertilizer losses and protect groundwater quality $[17,28]$. There has been no investigation of this possibility in pomegranate orchards.

A field experiment was conducted from 2010 to 2015 using high-frequency DI and subsurface (SDI) and fertigation to determine water and $\mathrm{N}$ requirements and yield response for pomegranate $\mathrm{cv}$. Wonderful in the San Joaquin Valley, California [17]. Based on a lack of differences in yield among three levels of $\mathrm{N}$ application, the $\mathrm{N}$ requirement for a 4-6-year-old pomegranate orchard was concluded to be in the range of 62 to $112 \mathrm{~kg} / \mathrm{ha}$ (109-198 g/tree), which is lower than what is used in current commercial practice. Although total yield was not significantly different between DI and SDI, SDI used less water by design, which resulted in less weed growth, and sometimes resulted in significantly higher either prime or subprime fruit yield compared to DI. Ayars et al. [17] did not examine $\mathrm{N}$ uptake data and how the irrigation systems and $\mathrm{N}$ treatment levels may have affected $\mathrm{C}$ and $\mathrm{N}$ dynamics. We hypothesized that the different drip irrigation systems significantly impact $\mathrm{C}$ and $\mathrm{N}$ distribution and transport in the soil profile, and that effective management practices could be developed with proper levels of $\mathrm{N}$ application for high yield and reduced environmental risks. The objective of this research 
was to determine the effect of high-frequency DI and SDI and different levels of applied fertilizer $\mathrm{N}$ on $\mathrm{C}$ and $\mathrm{N}$ distribution in the soil, in pomegranate leaf tissue, and total $\mathrm{N}$ uptake.

\section{Materials and Methods}

\subsection{Study Site}

The study was conducted in a 1.4 ha pomegranate (Punica granatum L. cv. Wonderful) orchard at the University of California Kearney Agricultural Research and Extension Center (UC-KARE) located near Parlier, CA ( $36^{\circ} 36^{\prime} 3^{\prime \prime} \mathrm{N} ; 119^{\circ} 30^{\prime} 39^{\prime \prime} \mathrm{W}$; $103 \mathrm{~m}$ elevation). The soil at the experimental site is classified as Hanford sandy loam (coarse-loamy, mixed, superactive, non-acid, thermic Typic Xerorthents). The soil had a pH $7.5\left(1: 20.01 \mathrm{M} \mathrm{CaCl}_{2}\right) ; \mathrm{EC}_{25}(1: 1) 171 \mu \mathrm{S} \mathrm{cm}^{-1}$; and field capacity $\sim 17 \%$. The climate is classified as Mediterranean, characterized by mild wet winters and hot dry summers with low annual precipitation occurring primarily in winter. The average annual precipitation is about $200 \mathrm{~mm}$, but annual potential evapotranspiration (ETo) is approximately $1350 \mathrm{~mm}$. All agriculture in the region is irrigated. Young pomegranate trees about $0.91 \mathrm{~m}$ in height were planted in April 2010 with a $4.9 \mathrm{~m}$ row spacing and a $3.6 \mathrm{~m}$ tree spacing within a row ( 567 trees/ha).

The experimental design was a split-plot, with two irrigation methods as main plot treatments and three $\mathrm{N}$ fertilization rates as the sub-plot treatments with five replicates. The main plot treatments were DI and SDI with the laterals installed on the surface or at a depth of approximately $55 \mathrm{~cm}$, respectively. Both drip systems had two laterals per tree row, one on each side of the tree row at a distance of $1.1 \mathrm{~m}$ from the center of the tree line. The emitters applied water at $2 \mathrm{~L} / \mathrm{h}$ and were spaced $0.46 \mathrm{~m}$ apart along the lateral. During the spring and summer of the first year (2010), while the SDI system was installed and the control pad was finished, all the trees were irrigated manually to ensure that they received enough water during the early growth stage. The same irrigation and $\mathrm{N}$ rates were applied to the entire orchard during the first two years (2010-2011) to ensure uniform plant establishment. The trees were around $2.44 \mathrm{~m}$ in height at the time $\mathrm{N}$ treatments started in 2012. Once the $\mathrm{N}$ treatments started, all the trees, including a lysimeter tree, were minimally pruned to maintain a bush-like shape and mechanically pruned at a height of $3.0 \mathrm{~m}$ [29]. Details about the field design and treatments can be found in Ayars et al. [17].

A large automated lysimeter $(4 \mathrm{~m}$ long $\times 2 \mathrm{~m}$ wide $\times 2 \mathrm{~m}$ deep) containing one tree was used to manage the irrigation scheduling of the experimental site [17,30,31]. The lysimeter tree was irrigated using SDI treatment with the same number of emitters as the trees in the field. The trees in all $\mathrm{N}$ treatments were irrigated at $100 \%$ of crop water replacement as measured by the lysimeter. Three $\mathrm{N}$ rate treatments (N1, N2, and N3) started in 2012 and continued to the end of December 2015. In 2012, the trees received 52, 165, and $279 \mathrm{~kg} \mathrm{~N} / \mathrm{h}$ for N1, N2, and N3, respectively. As the trees grew larger, the N application rate increased. In 2013, the trees received 70, 166, and $245 \mathrm{~kg} \mathrm{~N} / \mathrm{ha}$ for N1, $\mathrm{N} 2$, and N3, respectively. In 2014, the trees received 62, 223, and $342 \mathrm{~kg} \mathrm{~N} / \mathrm{ha}$ for N1, N2, and N3, respectively. In 2015, the trees received 113, 263, and $331 \mathrm{~kg} \mathrm{~N} /$ ha for N1, N2, and N3, respectively. All $\mathrm{N}$ was applied through fertigation. N-pHURIC ${ }^{\circledR} 10 / 55$ (urea and sulfuric acid with $10 \% \mathrm{~N}$ and $18 \% \mathrm{~S}$ ) was applied to all levels of $\mathrm{N}$ treatments. The $\mathrm{N}$-pHURIC ${ }^{\circledR}$ was used also to maintain the irrigation water at $\mathrm{pH} 6.5$ to prevent precipitation of phosphates. For the additional $\mathrm{N}$ requirement in $\mathrm{N} 2$ and $\mathrm{N} 3$, ammonium nitrate $\left(20 \% \mathrm{~N}\right.$ or AN20) was injected. Phosphoric acid $\left(\mathrm{H}_{3} \mathrm{PO}_{4}\right)$ and potassium thiosulfate $(25 \% \mathrm{~K}, 17.5 \% \mathrm{~S})$ were injected to all treatments at the same rate. The rate increased as trees grew larger. In 2013, all trees received 66 and $73 \mathrm{~kg} / \mathrm{ha}$ of $\mathrm{P}$ and K, respectively. In 2014, all trees received 92 and 85 $\mathrm{kg} / \mathrm{ha}$ of $\mathrm{P}$ and $\mathrm{K}$, respectively. In 2015, all trees received 116 and $181 \mathrm{~kg} / \mathrm{ha}$ of $\mathrm{P}$ and $\mathrm{K}$, respectively. In 2012, when the differential N treatments were begun, an additional $10 \%$ water was applied to the DI treatments to compensate for potentially increased evaporative water loss and the weed growth that was controlled during the growing season. The trees were irrigated after $1 \mathrm{~mm}$ of crop water use had been measured in the lysimeter. During peak crop water use, this resulted in up to 8 to $10 \mathrm{~mm}$ per day. More details about the field and lysimeter operation are given in Ayars et al. [17]. 


\subsection{Soil Measurements}

Soil samples were collected twice a year (early spring before irrigation and fall after harvest but before the rainy season started) from 2012 to 2013 to determine total C, total N, and DOC. Samples were collected from all five treatment plots at eight soil depths (cm): 0-15, 15-30, 30-45, 45-60, 60-75, 75-90, 90-105, and 105-120 using a $7.6 \mathrm{~cm}$ diameter soil auger, oven dried at $65^{\circ} \mathrm{C}$ for $48 \mathrm{~h}$, ground with a Model 4-E Grinding Mill (QCG Systems, LLC, Phoenixville, PA, USA), and sieved through a $2 \mathrm{~mm}$ screen. Total $\mathrm{C}$ and total $\mathrm{N}$ contents were determined by dry combustion with a Flash $2000 \mathrm{~N} \&$ C Soil Analyzer (Thermo Scientific ${ }^{\circledR}$, Pittsburgh, PA, USA). The DOC and $\mathrm{NO}_{3}{ }^{-}$concentrations were determined after mixing the soil with deionized water (1:1 soil:water) for $24 \mathrm{~h}$, shaken for $1 \mathrm{~h}$ on a reciprocating shaker, and vacuum filtered through Whatman no. 42 filter paper. Carbon recovered in the water extract was determined using a Fusion Total Organic Carbon Analyzer TM (Teledyne Tekmar, Mason, $\mathrm{OH}, \mathrm{USA}$ ). $\mathrm{NO}_{3}{ }^{-}$concentration was determined using an Astoria 2 Analyzer (Astoria Pacific Inc., Clackamas, OR, USA), and soil samples collected from 2012-2014 were analyzed.

\subsection{Plant Measurements}

Tree leaves were collected biweekly beginning in May 2012 and continuing to the end of September 2014 to determine effects of the irrigation system and $\mathrm{N}$ treatment on leaf $\mathrm{N}$ concentration as an indicator of tree $\mathrm{N}$ status [32]. Data for 2015 were reported in Ayars et al. [17]. The present paper presents the data up to 2014, when fruit samples were collected after harvest, to evaluate $\mathrm{N}$ distribution and uptake by the crop. Leaf samples were washed with deionized water, oven dried at $65^{\circ} \mathrm{C}$, and ground with an UDY Cyclone Sample Mill (UDY Corp., Fort Collins, CO, USA). Total N and C in the plant samples were measured using the same dry combustion method as for the soil samples. Since the changes in leaf concentrations during the growing season from May through September did not differ among treatments [17], the average values of all samples during this period of time each year were used for $\mathrm{N}$ uptake and $\mathrm{C}$ interpretation.

At harvest in October 2014, pomegranate fruit samples were collected from all treatments and replicates. The fruit were separated into arils and peels and were processed similarly to the leaves for analysis. Average fruit $\mathrm{N}$ concentrations were calculated based on weight ratio of arils to peels and were then used to estimate total $\mathrm{N}$ uptake in fruit by multiplying by the yield (yield data were reported by Ayars et al. [17]).

The MIXED procedure of SAS version 9.4 (SAS Institute, Cary, NC, USA) was used to fit a repeated measure mixed model. The fixed effects were irrigation type, $\mathrm{N}$ rate, soil depth, and their interactions. The random effects were replications (rep), irrigation $\times$ rep, and irrigation $\times \mathrm{N} \times$ rep. The latter interaction was used to define the experimental units for incorporating a first order, autoregressive covariance structure among the repeated measures in depth.

Focus was on the irrigation type and $\mathrm{N}$ rate effects, for which the least square means and their $95 \%$ confidence intervals were obtained. If TC was not detectable (ND), a zero value was used for analyses.

\section{Results and Discussion}

\subsection{Soil Total $C$ and $N$ in Different Irrigation and $N$ Treatments}

Significant differences $(p<0.05)$ in soil TC concentration at the same depth between N treatments within irrigation type are shown in Table 1. In 2012, greater TC was observed in N3DI (0.3-0.8\%) than in N1DI $(<0.02 \%)$ and N2DI $(0.02-0.04 \%)$ treatments in upper soil depths of $0-75 \mathrm{~cm}$. However, greater TC was found in N3SDI $(0.4-0.8 \%)$ than the other $\mathrm{N}$ treatments at $75-120 \mathrm{~cm}$ depths $(<0.01 \%)$. TC in $\mathrm{N} 1$ and N2 treatments was low throughout the profile under both DI and SDI. At depths $75 \mathrm{~cm}$ the TC was ND in all DI treatments including N3DI, while in the SDI treatment, TC was significantly lower at $0-45 \mathrm{~cm}$ depth in the N3 treatment. The occurrence of high TC in the N3SDI treatment corresponded to the placement of the drip tubing $(\sim 50 \mathrm{~cm})$ where fertilizer was delivered. 
Table 1. Soil total C concentrations $(\%)$ in soil profile $(0-120 \mathrm{~cm})$ under different irrigation systems and N levels for 2012 and 2013.

\begin{tabular}{|c|c|c|c|c|c|c|c|c|c|c|c|c|}
\hline \multirow{3}{*}{ Soil Depth } & \multicolumn{6}{|c|}{ Treatments (2012) } & \multicolumn{6}{|c|}{ Treatments (2013) } \\
\hline & \multicolumn{3}{|c|}{ Drip Irrigation } & \multicolumn{3}{|c|}{$\begin{array}{l}\text { Subsurface Drip } \\
\text { Irrigation }\end{array}$} & \multicolumn{3}{|c|}{ Drip Irrigation } & \multicolumn{3}{|c|}{ Subsurface Drip Irrigation } \\
\hline & $\mathrm{N} 1^{\mathrm{z}}$ & N2 & N3 & N1 & N2 & N3 & N1 & N2 & N3 & N1 & N2 & N3 \\
\hline$(\mathrm{cm})$ & \multicolumn{6}{|c|}{$(\%)$} & \multicolumn{6}{|c|}{$(\%)$} \\
\hline $0-15$ & $0.02 \mathrm{~b}^{\mathrm{y}}$ & $0.04 \mathrm{~b}$ & $0.82 \mathrm{a}$ & $0.02 \mathrm{a}$ & $0.08 \mathrm{a}$ & $0.03 \mathrm{a}$ & $1.11 \mathrm{~b}$ & $1.42 \mathrm{~b}$ & $3.73 \mathrm{a}$ & $0.1 \mathrm{~b}$ & $0.1 \mathrm{~b}$ & $1.03 \mathrm{a}$ \\
\hline $15-30$ & $\mathrm{ND} b$ & $0.02 \mathrm{~b}$ & $0.78 \mathrm{a}$ & $0.01 \mathrm{a}$ & $0.03 \mathrm{a}$ & $0.01 \mathrm{a}$ & $1.15 \mathrm{~b}$ & $1.27 \mathrm{~b}$ & $3.26 \mathrm{a}$ & $0.24 b$ & $0.15 \mathrm{~b}$ & $1.19 \mathrm{a}$ \\
\hline $30-45$ & $\mathrm{ND} b$ & $0.02 \mathrm{~b}$ & $0.74 \mathrm{a}$ & $0.01 \mathrm{a}$ & $0.02 \mathrm{a}$ & $0.01 \mathrm{a}$ & $1.13 \mathrm{~b}$ & $1.18 \mathrm{~b}$ & $1.87 \mathrm{a}$ & $0.36 \mathrm{~b}$ & $0.2 \mathrm{~b}$ & $1.19 \mathrm{a}$ \\
\hline $45-60$ & $\mathrm{ND} b$ & $0.02 \mathrm{~b}$ & $0.46 \mathrm{a}$ & $0.01 \mathrm{~b}$ & $0.03 \mathrm{~b}$ & $0.24 \mathrm{a}$ & $1.1 \mathrm{a}$ & $1.06 \mathrm{a}$ & $1.06 \mathrm{a}$ & $1.27 \mathrm{~b}$ & $1.02 \mathrm{~b}$ & $3.73 \mathrm{a}$ \\
\hline $60-75$ & $\mathrm{ND} b$ & $0.02 \mathrm{~b}$ & $0.28 \mathrm{a}$ & $0.01 \mathrm{~b}$ & $0.06 \mathrm{~b}$ & $0.76 \mathrm{a}$ & $0.48 \mathrm{~b}$ & $0.9 \mathrm{a}$ & $0.06 \mathrm{c}$ & $0.9 \mathrm{~b}$ & $0.03 \mathrm{~b}$ & $2.38 \mathrm{a}$ \\
\hline $75-90$ & ND & ND & ND & $0.01 \mathrm{a}$ & $0.01 \mathrm{a}$ & $0.68 \mathrm{a}$ & $0.18 \mathrm{a}$ & $0.11 \mathrm{a}$ & $0.06 \mathrm{a}$ & $0.48 \mathrm{~b}$ & $0.04 \mathrm{~b}$ & $2.1 \mathrm{a}$ \\
\hline 90-105 & ND & ND & ND & $0.01 \mathrm{~b}$ & $\mathrm{ND} \mathrm{b}$ & $0.54 \mathrm{a}$ & $0.1 \mathrm{a}$ & $0.06 \mathrm{a}$ & $0.02 \mathrm{a}$ & $0.18 \mathrm{~b}$ & $0.04 \mathrm{~b}$ & $2.1 \mathrm{a}$ \\
\hline $105-120$ & ND & ND & ND & $\mathrm{ND} \mathrm{b}$ & $\mathrm{ND} b$ & $0.43 \mathrm{a}$ & $0.03 \mathrm{a}$ & $0.05 \mathrm{a}$ & $0.02 \mathrm{a}$ & $0.00 \mathrm{~b}$ & $0.03 \mathrm{~b}$ & $1.06 \mathrm{a}$ \\
\hline
\end{tabular}

${ }^{\mathrm{z}} \mathrm{N} 1=(\mathrm{N}=52-70 \mathrm{~kg} / \mathrm{ha}$ in 2012-2013), N2 = (N = 165-166 kg/ha), N3 = (N = 245-279 kg/ha), and ND = non-detectable (zero percentage). ${ }^{y}$ followed by the same letter between treatments for each soil depth within the year indicates no significant difference at $p<0.05$.

In 2013, the TC percentage generally increased in all soil profiles in all treatments, up to $4 \times(\sim 3.7 \%)$ times higher than in 2012 (Table 1). A similar distribution pattern of TC in 2013 to that in 2012 was observed. In the DI treatment, greater TC was found in the upper $60 \mathrm{~cm}$ of the soil in all levels of N treatments. TC decreased as soil depth increased and dropped to the ND at a $120 \mathrm{~cm}$ soil depth. The TC in N3DI was 2-3x that from the other two N treatments at $0-30 \mathrm{~cm}$. In the SDI plots, TC was higher in N3 than all corresponding depths in N1 and N2 (average 1.5\%), and was the highest at 45-60 cm in the profile.

There were significant effects of irrigation by $\mathrm{N}(p<0.05)$ on TN in soil in 2012 and 2013. Total N distribution followed a similar pattern to the TC distribution with higher TN in the upper soil profile under DI and subsurface soil under SDI, and higher concentrations in N3 than N1 and N2 (Table 2). In 2012, higher concentrations of TN were found in the upper $45 \mathrm{~cm}$ of soil for N3DI compared with the remaining $\mathrm{N}$ treatments. The N3SDI soils had the highest $\mathrm{TN}$ at a $30-75 \mathrm{~cm}$ depth, which was greater than the other treatment combinations. At depths $>75 \mathrm{~cm}$, all TN concentrations were low, and some were not detectable at 105-120 cm depths, indicating that $\mathrm{N}$ storage did not increase at this depth under high-frequency DI management. TN concentrations increased with increased depth in 2013 compared to 2012. Greater concentrations of TN were found in the upper $75 \mathrm{~cm}$ of soil in all N levels under DI with the highest under N3DI, but all dropped significantly with no differences among treatments below $75 \mathrm{~cm}$ soil depth. Under SDI, higher TN concentrations in 2013 were found only in N3SDI at a 75-90 cm depth compared with the other $\mathrm{N}$ treatments.

Table 2. Soil total N concentrations $(\%)$ in soil profile $(0-120 \mathrm{~cm})$ under different irrigation systems and $\mathrm{N}$ levels for 2012 and 2013.

\begin{tabular}{|c|c|c|c|c|c|c|c|c|c|c|c|c|}
\hline \multirow{3}{*}{ Soil Depth } & \multicolumn{6}{|c|}{ Treatments (2012) } & \multicolumn{6}{|c|}{ Treatments (2013) } \\
\hline & \multicolumn{3}{|c|}{ Drip Irrigation } & \multicolumn{3}{|c|}{$\begin{array}{c}\text { Subsurface Drip } \\
\text { Irrigation }\end{array}$} & \multicolumn{3}{|c|}{ Drip Irrigation } & \multicolumn{3}{|c|}{ Subsurface Drip Irrigation } \\
\hline & N1 ${ }^{z}$ & N2 & N3 & N1 & N2 & N3 & N1 & N2 & N3 & N1 & N2 & N3 \\
\hline (cm) & \multicolumn{6}{|c|}{$(\%)$} & \multicolumn{6}{|c|}{$(\%)$} \\
\hline $0-15$ & $0.12 \mathrm{c}^{\mathrm{y}}$ & $0.38 \mathrm{~b}$ & $0.82 \mathrm{a}$ & $0.01 \mathrm{a}$ & $0.11 \mathrm{a}$ & $0.11 \mathrm{a}$ & $0.27 \mathrm{~b}$ & $0.35 \mathrm{~b}$ & $0.91 \mathrm{a}$ & $0.11 \mathrm{a}$ & $0.06 \mathrm{a}$ & $0.09 \mathrm{a}$ \\
\hline $15-30$ & $0.11 \mathrm{c}$ & $0.32 \mathrm{~b}$ & $0.76 \mathrm{a}$ & $0.04 \mathrm{a}$ & $0.09 \mathrm{a}$ & $0.11 \mathrm{a}$ & $0.26 \mathrm{~b}$ & $0.25 \mathrm{~b}$ & $0.72 \mathrm{a}$ & $0.13 \mathrm{a}$ & $0.08 \mathrm{a}$ & $0.02 \mathrm{a}$ \\
\hline $30-45$ & $0.12 \mathrm{c}$ & $0.28 \mathrm{~b}$ & $0.37 \mathrm{a}$ & $0.05 \mathrm{~b}$ & $0.1 \mathrm{~b}$ & $0.56 \mathrm{a}$ & $0.23 \mathrm{~b}$ & $0.28 \mathrm{~b}$ & $0.54 \mathrm{a}$ & $0.03 \mathrm{a}$ & $0.08 \mathrm{a}$ & $0.05 \mathrm{a}$ \\
\hline $45-60$ & $0.15 \mathrm{a}$ & $0.25 \mathrm{a}$ & $0.22 \mathrm{a}$ & $0.05 \mathrm{c}$ & $0.19 \mathrm{~b}$ & $0.29 \mathrm{a}$ & $0.12 \mathrm{~b}$ & $0.2 \mathrm{~b}$ & $0.54 \mathrm{a}$ & $\mathrm{ND}$ a & $0.1 \mathrm{a}$ & $0.02 \mathrm{a}$ \\
\hline $60-75$ & $0.03 \mathrm{a}$ & $0.11 \mathrm{a}$ & $0.1 \mathrm{a}$ & $0.08 \mathrm{~b}$ & $0.2 \mathrm{a}$ & $0.25 \mathrm{a}$ & $0.12 \mathrm{~b}$ & $0.1 \mathrm{~b}$ & $0.38 \mathrm{a}$ & ND c & $0.11 \mathrm{~b}$ & $0.32 \mathrm{a}$ \\
\hline $75-90$ & $0.03 \mathrm{a}$ & $0.13 \mathrm{a}$ & $0.07 \mathrm{a}$ & $0.07 \mathrm{a}$ & $0.22 \mathrm{a}$ & $0.07 \mathrm{a}$ & $0.06 \mathrm{a}$ & $0.11 \mathrm{a}$ & $0.02 \mathrm{a}$ & $\mathrm{ND} b$ & $0.04 b$ & $0.27 \mathrm{a}$ \\
\hline 90-105 & ND a & $0.18 \mathrm{a}$ & $0.07 \mathrm{a}$ & $0.07 \mathrm{a}$ & $0.2 \mathrm{a}$ & $0.05 \mathrm{a}$ & $0.04 \mathrm{a}$ & $0.04 \mathrm{a}$ & $0.02 \mathrm{a}$ & $\mathrm{ND} b$ & $0.04 \mathrm{~b}$ & $0.15 \mathrm{a}$ \\
\hline $105-120$ & $\mathrm{ND}$ a & $0.07 \mathrm{a}$ & $0.06 \mathrm{a}$ & $0.00 \mathrm{a}$ & $0.21 \mathrm{a}$ & $0.04 \mathrm{a}$ & $0.02 \mathrm{a}$ & $0.04 \mathrm{a}$ & $0.00 \mathrm{a}$ & $\mathrm{ND}$ a & $0.03 \mathrm{a}$ & $0.00 \mathrm{a}$ \\
\hline
\end{tabular}

${ }^{\mathrm{z}} \mathrm{N} 1=(\mathrm{N}=52-70 \mathrm{~kg} / \mathrm{ha}$ in 2012-2013), N2 = (N = 165-166 kg/ha), N3 = (N = 245-279 kg/ha), and ND = non-detectable (zero percentage). ${ }^{y}$ followed by the same letter between treatments for each soil depth within the year indicates no significant difference at $p<0.05$. 
In our study, the total $C$ in soil was low $(<1 \%)$ in 2012. In 2013, total $C$ increased up to $\sim 3.5 \%$ in soils treated with a higher $\mathrm{N}$ application rate (N3) in the upper profile of the soil $(0-30 \mathrm{~cm})$ under DI, and $\sim 3.0 \%$ in the subsurface profile $(45-75 \mathrm{~cm})$ under SDI. Higher TC with DI could have been attributed to weed growth (Ayars et al. [17]). Both TC and TN increases followed a similar pattern, i.e., in surface soil under DI and subsurface soil near the drip line under SDI. The higher TC values associated with higher $\mathrm{N}$ application rate indicated that $\mathrm{N}$ supply under adequate soil moisture must have benefited the production of microbial biomass. Decock et al. [33] found similar results in almond orchards in the upper $15 \mathrm{~cm}$ of well-drained, gravelly sandy loam soils (Arbuckle series-Typic Haploxeralfs) in California, which were irrigated with a microjet sprinkler system twice a week for a total of $380 \mathrm{~mm} / \mathrm{ha}$ y and fertilized with $\mathrm{N}$ (urea ammonium nitrate, $32 \% \mathrm{~N}$ ) three to five times a year up to $258-280 \mathrm{~kg} \mathrm{~N} / \mathrm{ha}$. They found that TC, TN, and C/N ratios were approximately $0.83 \%, 0.083 \%$, and 10, respectively. The increase in TC with time may have been explained by Wolf et al. [34], who reported that most crop systems experienced a small increase in soil $\mathrm{C}$ from both conventional and organic productions for annual crops. The larger TC (an average of $\sim 3.5 \%$ ) increase in our study with high-frequency DI in 2013 in the first $30 \mathrm{~cm}$ of the soil could indicate some advantage of DI in orchards that may promote soil organic carbon (OC) build-up to improve soil productivity, which warrants further in-depth investigation. Examination of soil total organic $C$ to $\mathrm{N}$ ratio (Figure 1) also indicated a very low ratio of 1:1 under DI, an undefinable ratio under SDI in 2012, and a C:N ratio increase to about 3.7:1 under DI and to 4.2:1 under SDI in 2013. In apple orchards in temperate climates, the C:N ratio ranged from 6.1-9.5:1 [35] and other reported values ranged from 10:1 to 19:1 [36]. As both soil OC and $\mathrm{N}$ play an important role in soil sustainability, a C:N ratio of 24:1 has been suggested to maintain soil health [37]. Under these optimum conditions, soil microbes can spur the release of nutrients like $\mathrm{N}, \mathrm{P}$, and $\mathrm{Zn}$ to crops while maintaining the necessary amount of soil-protecting residue. The lower $\mathrm{C}: \mathrm{N}$ ratio in our study was caused a result of low soil organic matter $(<1 \%)$ that suggests a need to increase soil OC to sustain or increase soil productivity in the region. The relatively higher C:N ratio under SDI may indicate some advantage over DI, which requires further investigation.
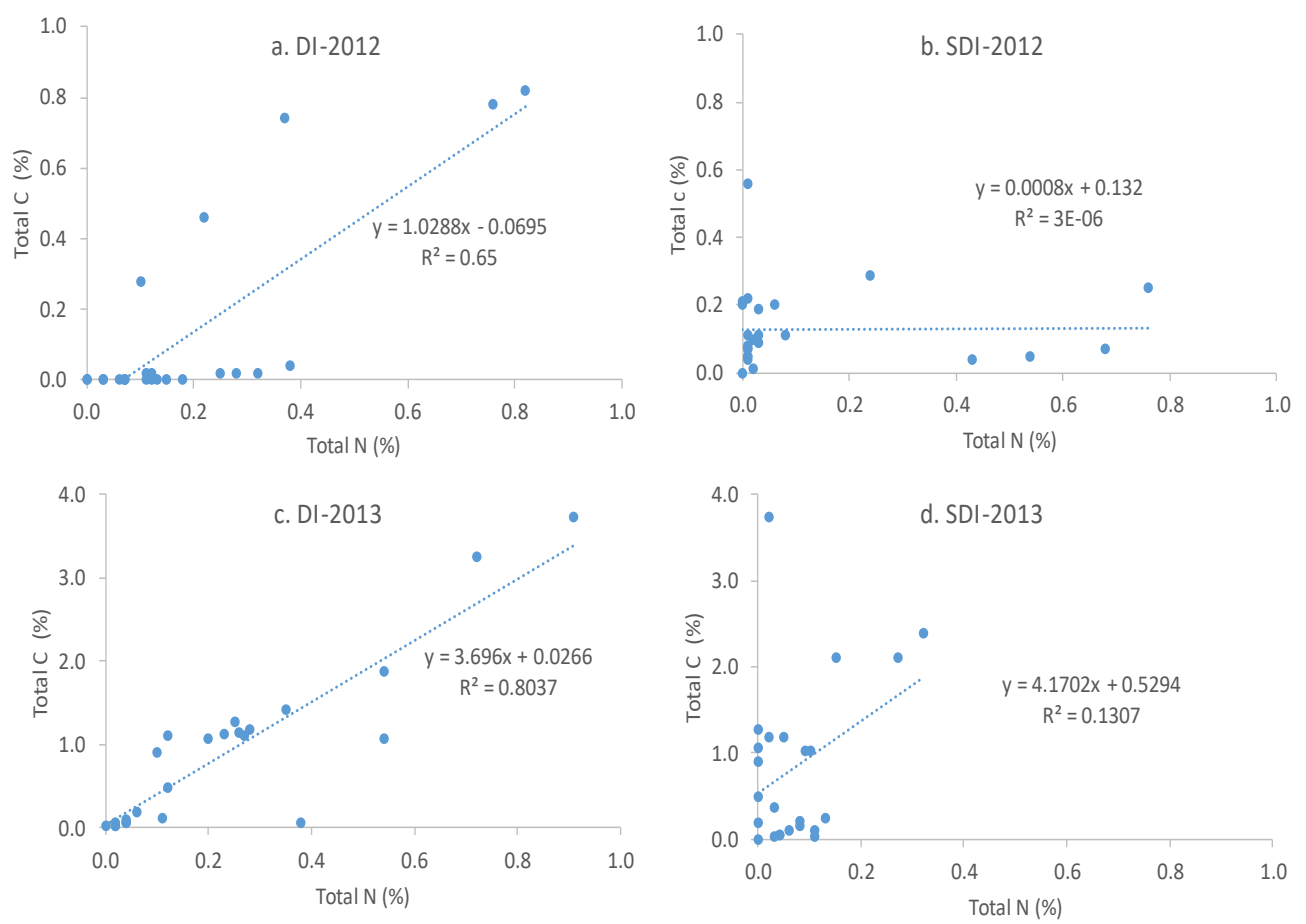

Figure 1. Correlation between soil total carbon and nitrogen under different irrigation systems (DI = drip irrigation and SDI = subsurface irrigation) for years 2012 and 2013. 


\subsection{Soil $\mathrm{DOC}$ and $\mathrm{NO}_{3}{ }^{-}$in Different Irrigation and $\mathrm{N}$ Treatments}

In both 2012 and 2013, DOC concentrations and distributions in soil were significantly affected by the irrigation type $\times \mathrm{N}$ rate interaction $(p<0.05)$. In 2012, under DI, a greater DOC was found in the upper $45 \mathrm{~cm}$ soil for N3 than N2, which had a significantly higher DOC than in N1 (Figure 2). There was no statistical difference for soil depths below $45 \mathrm{~cm}$. Under SDI, however, in addition to lower values in surface soils compared to those under DI, DOC concentration and distribution were all similar with no differences among the three levels of $\mathrm{N}$ treatments, which was likely due to a relatively dry surface with N applied at a greater depth. In 2013, greater DOC was found for N3 treatments than for N2 and N1 under both DI and SDI, with significantly higher concentrations in the upper $75 \mathrm{~cm}$ under DI and at $\leq 40 \mathrm{~cm}$ depth under SDI.
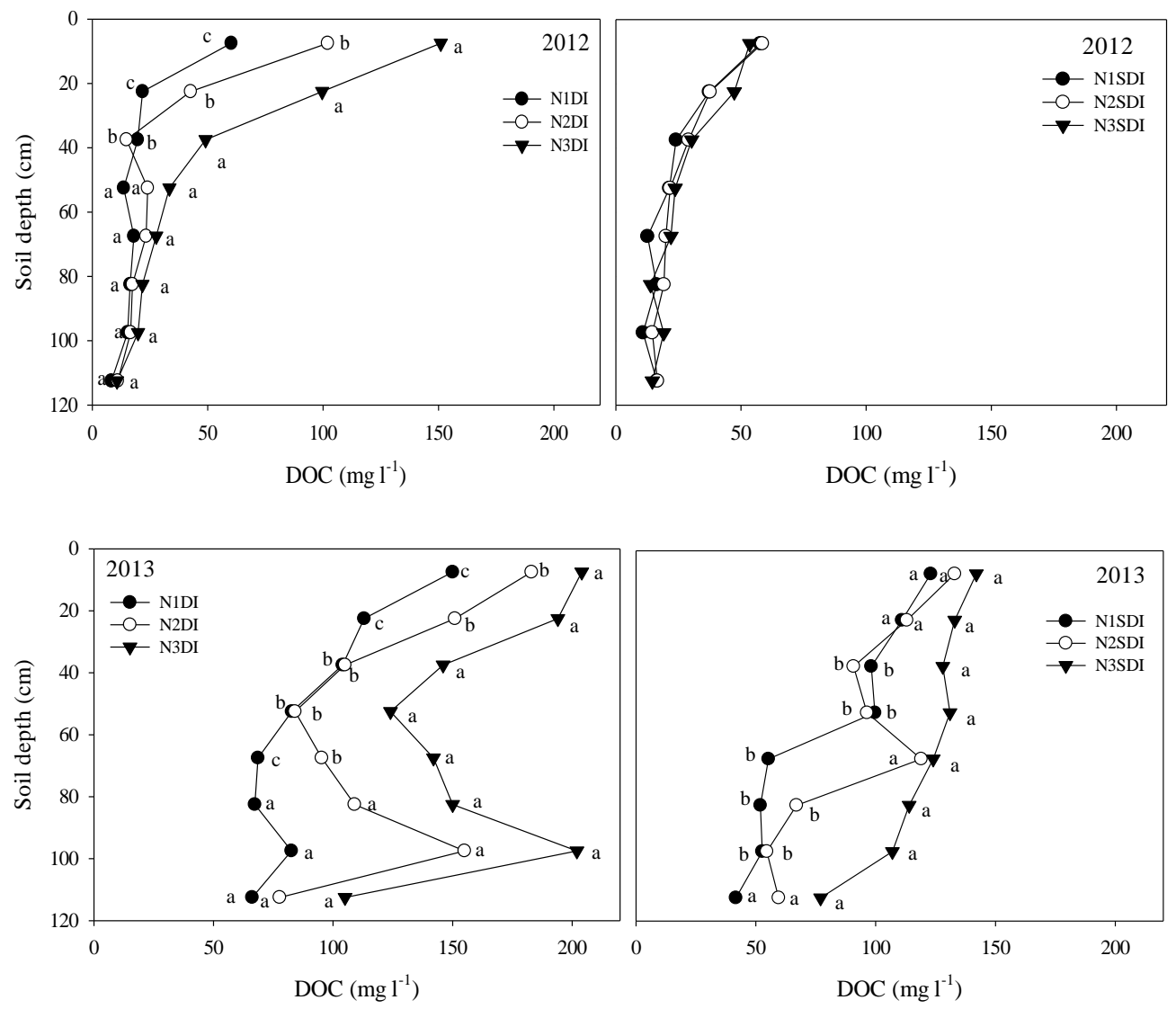

Figure 2. Concentrations of dissolved organic carbon (DOC) in a 1:1 mass soil extract using distilled water from soil samples collected under different irrigation systems and nitrogen levels for 2012-2013. Treatments: DI = drip irrigation, $S D I=$ subsurface irrigation, $N 1=(\mathrm{N}=52-70 \mathrm{~kg} / \mathrm{ha}$ in 2012-2013), $\mathrm{N} 2=(\mathrm{N}=165-166 \mathrm{~kg} / \mathrm{ha})$, and N3 = $(\mathrm{N}=245-279 \mathrm{~kg} / \mathrm{ha})$. Means followed by the same letter or no letters between treatments for each soil depth within the year were not significantly different at $p<0.05$.

For both 2012 and 2013, DOC concentration increased significantly from N1 to N2 to N3 under DI, and DOC concentrations from the N3 treatment under SDI were significantly higher than those from $\mathrm{N} 1$ and N2 in 2013 only. As DOC are the results of decomposition processes from organic materials, the data suggest that increased $\mathrm{N}$ level increased decomposition of soil organic materials. The effects of $\mathrm{N}$ on the decomposition of organic materials have been examined in several studies, including meta-analyses in recent years [38-41]. Nitrogen addition significantly impacted litter decomposition rate in Songnen meadow ecosystems [42]. Nitrogen fertilizer may increase the loss of cellulose, but it suppresses the breakdown of lignin in plant litter [43]. Similar conclusions were derived from meta-analyses indicating that $\mathrm{N}$ addition reduced the activity of lignin-modifying enzymes (LMEs), and this N-induced enzyme suppression was associated with increased soil organic C [39]. Jian et 
al. [40] showed that $\mathrm{N}$ fertilization significantly increased some enzyme activities while decreasing others after analyzing data from 65 published studies. Nitrogen fertilization generally enhanced SOC and TN but inhibited soil microbial biomass carbon. The contrasting effects of $\mathrm{N}$ addition on cellulose (hydrolytic C-degrading enzymes) and ligninase (oxidative C-degrading enzymes) activities were summarized by Luo et al. [41], who concluded that N-enhanced cellulose activity contributed to a minor stimulation of soil respiration, whereas $\mathrm{N}$-induced repression on ligninase activities led to soil $\mathrm{C}$ sequestration. The net results were increased DOC with increased $\mathrm{N}$ level treatments in our field study.

Nitrate distribution in soil was also significantly affected by irrigation and $\mathrm{N}$ rate interactions $(p<0.05)$. In 2012, higher $\mathrm{NO}_{3}{ }^{-}$was found under N3 compared with the other two levels of $\mathrm{N}$ under DI in the upper $60 \mathrm{~cm}$ of soil (Figure 3). Under SDI, higher $\mathrm{NO}_{3}{ }^{-}$concentrations were observed for N3 versus the other two N levels at $30-60 \mathrm{~cm}$ soil depths. The generally higher concentrations in SDI treatments or no difference from the DI treatments in the upper profile may be attributed to the carry-over from the previous year, as no $\mathrm{N}$ was applied to the surface in 2011. In 2013, higher $\mathrm{NO}_{3}{ }^{-}$ was found under N3 and N2 compared with N1 under DI in the upper $30 \mathrm{~cm}$ soil and also at greater depths $(90-120 \mathrm{~cm})$. The increased $\mathrm{NO}_{3}{ }^{-}$concentration at greater soil depths may indicate that leaching occurred in $\mathrm{N} 3$ treatments. For SDI, greater $\mathrm{NO}_{3}{ }^{-}$concentrations were found at $45-75 \mathrm{~cm}$ soil depth from $\mathrm{N} 3$ and $\mathrm{N} 2$ compared with $\mathrm{N} 1$. $\mathrm{As}^{\mathrm{NO}_{3}}{ }^{-}$is highly mobile in soil, the much higher concentrations at $30-40 \mathrm{~cm}$ depths might reflect a temporary increase from the downward movement of surface $\mathrm{NO}_{3}{ }^{-}$ in early spring, which is supported by the reduced concentration from 2012 to 2013 in the upper $20 \mathrm{~cm}$ of soils. In 2014, higher $\mathrm{NO}_{3}{ }^{-}$was again found below $80 \mathrm{~cm}$ soil under DI from N3 and N2 compared with $\mathrm{N} 1$, while under SDI, greater $\mathrm{NO}_{3}{ }^{-}$concentration was determined in subsurface soil at $30-75 \mathrm{~cm}$ depths from $\mathrm{N} 3$ versus the other two $\mathrm{N}$ levels. These data indicate that higher leaching could have occurred due to excessive N from N3 than N1 and N2 treatments. Excluding N3 treatments, the soil profile data showed more $\mathrm{N}$ storage in DI than SDI, which could be partially due to higher $\mathrm{N}$ plant uptake from SDI. In any case, the higher storage of $\mathrm{NO}_{3}{ }^{-}$under DI means higher leaching loss when the rainy season arrives.
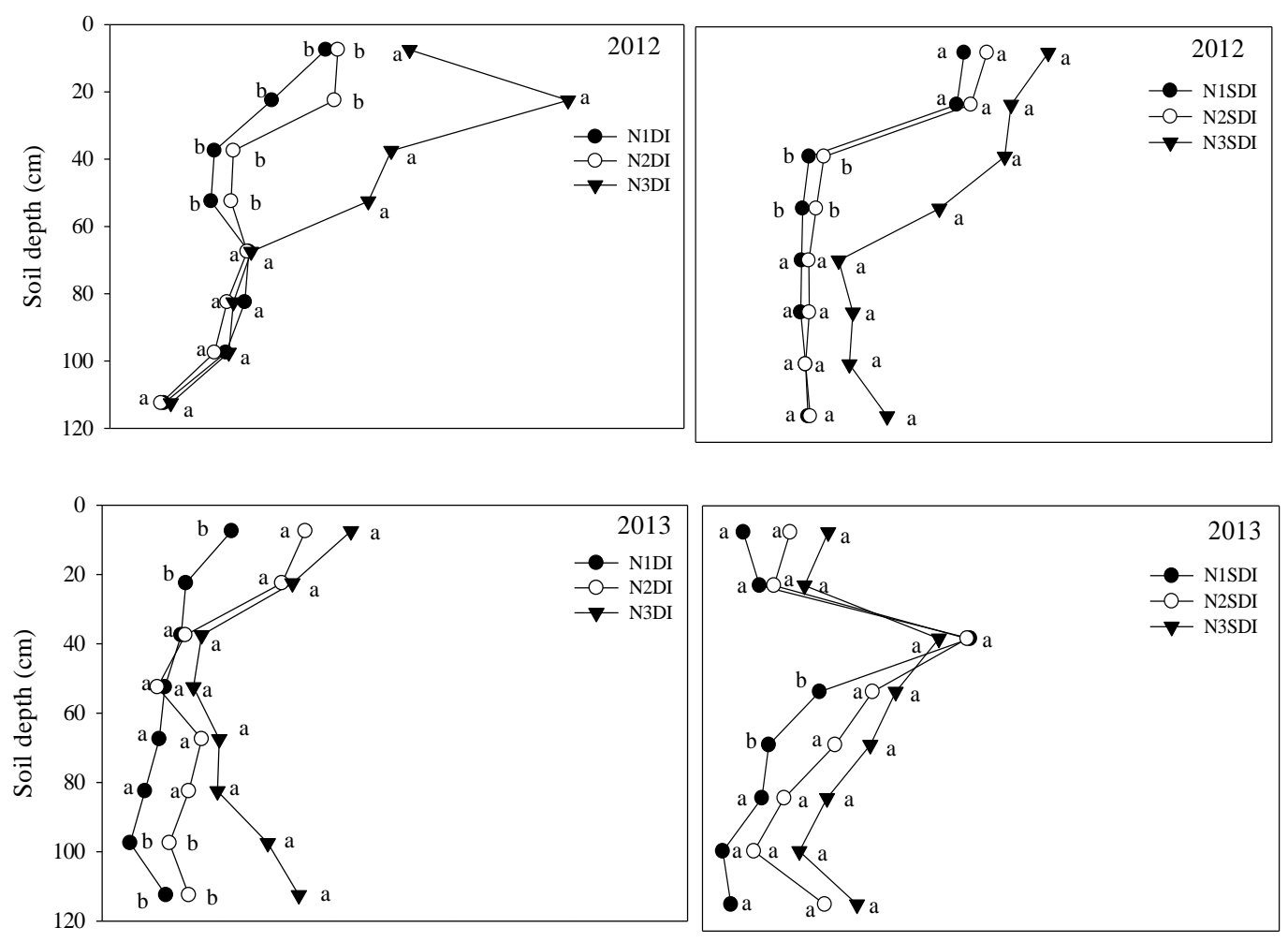

Figure 3. Cont. 

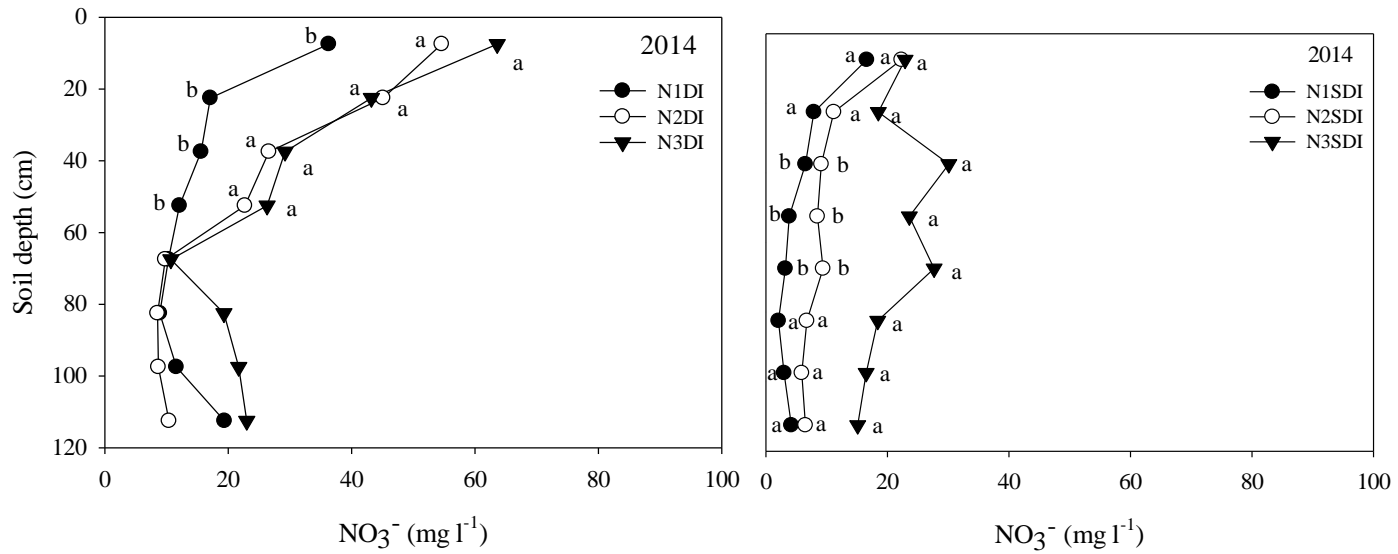

Figure 3. Concentrations of nitrates $\left(\mathrm{NO}_{3}{ }^{-}\right)$in a 1:1 mass soil extract using distilled water from soil samples collected under different irrigation systems and nitrogen levels for 2012-2014. Treatments: DI = drip irrigation, SDI = subsurface irrigation, $\mathrm{N} 1=(\mathrm{N}=52-70 \mathrm{~kg} / \mathrm{ha}$ in 2012-2013), $\mathrm{N} 2=(\mathrm{N}=165-166 \mathrm{~kg} / \mathrm{ha})$, and N3 = $(\mathrm{N}=245-279 \mathrm{~kg} / \mathrm{ha})$. Means followed by the same letter or no letters between treatments for each soil depth within the year were not significantly different at $p<0.05$.

Our data revealed the significant impact of irrigation type and $\mathrm{N}$ level on soil $\mathrm{C}$ and $\mathrm{N}$ mobility. DOC and $\mathrm{NO}_{3}{ }^{-}$availability and movement through the soil profile are influenced by not only soil texture and local climate, but also by agricultural practices such as irrigation type, application of different rates of $\mathrm{N}$, fertigation practices, and vegetation cover versus bare soil [38]. DOC concentrations can be used as an indicator of substrate availability of readily available $\mathrm{C}$ and $\mathrm{NO}_{3}{ }^{-}$concentrations for denitrification [33]. Gu et al. [44] found higher DOC ( 23\%) in the first $40 \mathrm{~cm}$ of soil of an established citrus orchard growing in a sandy loam soil covered with grass versus bare soil. They suggested that higher DOC could be responsible for the growth of vegetation, reduction of soil temperatures, and evaporation of water. In our study, we found that higher DOC was associated with higher $\mathrm{N}$ application and increased with crop years (i.e., from 2012 to 2013). Over time, leaves falling from these deciduous trees may lead to increased surface soil organic materials. Also observed in 2012 was a 2 to $3 \times$ higher DOC in surface soil (up to $45 \mathrm{~cm}$ of soil depth) under the DI system compared with SDI, which was partially attributed to weed growth. Ayars et al. [17] reported weed biomass $7 \times$ higher under a DI $\left(589 \mathrm{~g} / \mathrm{m}^{2}\right)$ versus a SDI $\left(81 \mathrm{~g} / \mathrm{m}^{2}\right)$ system, and $1.5 \times$ higher from N3 or N2 $\left(\sim 365 \mathrm{~g} / \mathrm{m}^{2}\right)$ than N1 $\left(\sim 250 \mathrm{~g} / \mathrm{m}^{2}\right)$. Decock et al. [33] found that in almond orchards growing in sandy loam soils in California irrigated with microjet sprinkler system and fertilized with $\mathrm{N}$ up to $258-280 \mathrm{~kg} \mathrm{~N} / \mathrm{ha} \mathrm{y}, \mathrm{NO}_{3}{ }^{-}$ concentrations typically increased following fertilizer application. The $\mathrm{NO}_{3}{ }^{-}$and $\mathrm{DOC}$ concentrations in the top $15 \mathrm{~cm}$ of the soil ranged between $0-128 \mathrm{mg} / \mathrm{L}$ and $0-310 \mathrm{mg} / \mathrm{L}$, respectively, from samples collected in the tree row.

\subsection{Total $N$ Concentration and $C / N$ Ratio in Leaves}

Total $\mathrm{N}$ in tree leaves was analyzed multiple times in each year and was used to characterize the response to the $\mathrm{N}$ treatments. The main effects are shown in Table 3, where no significant effect was found for the irrigation by $\mathrm{N}$ rate interaction $(p>0.05)$. TC exhibited similar values ranging from $48 \%-56 \%$ for years $2012-2014$. The TN and C/N ratios were only significantly affected by the main effects. Higher TN was found in DI versus SDI treatment in 2012 only. Additionally, about $5 \%$ higher $\mathrm{TN}$ was found in $\mathrm{N} 2$ and N3 compared with N1 trees in 2013. For the $\mathrm{C} / \mathrm{N}$ ratio, a higher value was found in SDI versus DI in 2012. In addition, a higher C/N ratio was found in N1 versus N2 or N3 treatments in 2012 and 2014. Based on the results, there were no significant differences between N2 and $\mathrm{N} 3$, indicating that $\mathrm{N} 2$ application was sufficient to meet pomegranate tree demands for maximum uptake. Sebastian et al. [45] reported that in mature almond orchards growing in California, leaf $\mathrm{N}$ concentration was significantly higher from $>224 \mathrm{~kg} \mathrm{~N} / \mathrm{ha}$ application rates than from $140 \mathrm{~kg} \mathrm{~N} / \mathrm{ha}$. 
Table 3. Total $\mathrm{N}$ and $\mathrm{C} / \mathrm{N}$ ratio of pomegranate leaf tissue samples treated with three levels of $\mathrm{N}$ under two irrigation systems.

\begin{tabular}{|c|c|c|c|c|c|c|c|c|c|c|}
\hline \multirow{3}{*}{ Year } & \multicolumn{5}{|c|}{ Total N (\%) } & \multicolumn{5}{|c|}{ C/N Ratio } \\
\hline & \multicolumn{2}{|c|}{ Irrigation } & \multicolumn{3}{|c|}{ N Rate } & \multicolumn{2}{|c|}{ Irrigation } & \multicolumn{3}{|c|}{ N Rate } \\
\hline & DI $^{\mathrm{z}}$ & SDI & N1 ${ }^{y}$ & N2 & N3 & DI & SDI & N1 & N2 & N3 \\
\hline 2012 & $1.70 \mathrm{a}^{\mathrm{x}}$ & $1.65 \mathrm{~b}$ & 1.64 & 1.69 & 1.70 & $32.1 \mathrm{~b}$ & $32.4 \mathrm{a}$ & $32.8 \mathrm{a}$ & $31.3 \mathrm{~b}$ & $31.8 \mathrm{~b}$ \\
\hline 2013 & $1.94 \mathrm{a}$ & $1.93 \mathrm{a}$ & $1.88 \mathrm{~b}$ & $1.95 \mathrm{a}$ & $1.96 \mathrm{a}$ & $28.1 \mathrm{a}$ & $28.2 \mathrm{a}$ & $28.2 \mathrm{a}$ & $28.3 \mathrm{a}$ & $28.4 \mathrm{a}$ \\
\hline 2014 & $1.96 \mathrm{a}$ & $1.94 \mathrm{a}$ & $1.88 \mathrm{a}$ & $1.96 \mathrm{a}$ & $2.01 \mathrm{a}$ & $24.9 \mathrm{a}$ & $25.1 \mathrm{a}$ & $26.0 \mathrm{a}$ & $24.7 \mathrm{~b}$ & $24.4 \mathrm{~b}$ \\
\hline
\end{tabular}

$\mathrm{N}$ is highly mobile in plants, which contributed to the distribution pattern. Ayars et al. [17] reported that leaf $\mathrm{N}$ contents are significantly affected by the $\mathrm{N}$ rate and irrigation type $\times \mathrm{N}$ interactions, with reduced effects on $\mathrm{N}$ in fruit peels or arils. Although no biomass data were collected to estimate TN uptake by the trees, the lowest $\mathrm{N}$ concentrations in tree fruits from N1 (the only treatment with lower $\mathrm{N}$ concentration in fruits than branches) may suggest that the $\mathrm{N}$ supply from $\mathrm{N} 1$ was not sufficient to meet tree growth demands. However, results from Zhang et al. [29] demonstrated very little difference in canopy size due to irrigation types and $\mathrm{N}$ application. The lack of differences in the concentrations between N2 and N3 in the present study supported the conclusion that the N2 treatment provided sufficient $\mathrm{N}$ and the higher application at $\mathrm{N} 3$ was excessive for pomegranate tree growth.

\subsection{Total N Uptake by Fruit}

Data on total $\mathrm{N}$ uptake in fruit ( $\mathrm{N}$ concentration in fruit $\times$ yield) are shown in Table 4 . The $\mathrm{N}$ uptake was greater (by 10\%) with SDI treatment than with DI in 2014 and 2015. Meanwhile, for N treatments, a higher fruit N uptake occurred in the N2 and N3 treatments in 2013 and 2014, but not in 2015 when compared with N1. There were no significant differences $(p>0.05)$ in the N uptake between $\mathrm{N} 2$ and N3 treatments in any year. The data suggest that SDI resulted in a $\sim 1.1 \times$ higher $\mathrm{N}$ use efficiency than DI. However, the higher $\mathrm{N}$ application rate for $\mathrm{N} 3$ did not result in higher $\mathrm{N}$ uptake in comparison with the N2 rate. The data further support that the N2 rate $(120,138$, and $159 \mathrm{~kg} \mathrm{~N} / \mathrm{ha}$ for years 2013, 2014, and 2015, respectively) provided sufficient $\mathrm{N}$ for the crop.

Table 4. Fruit N uptake for 2013, 2014, and 2015 by irrigation systems and N levels.

\begin{tabular}{|c|c|c|c|c|}
\hline Year & Irrigation System & Fruit kg N/ha & N Treatment & Fruit kg N/ha \\
\hline \multicolumn{5}{|l|}{2013} \\
\hline & $\mathrm{DI}^{\mathrm{z}}$ & $105 a$ & $\mathrm{~N} 1 \mathrm{y}$ & $95 \mathrm{~b}$ \\
\hline & SDI & $113 \mathrm{a}$ & N2 & $120 \mathrm{a}$ \\
\hline & & & N3 & $112 \mathrm{a}$ \\
\hline \multicolumn{5}{|l|}{2014} \\
\hline & DI & $119 b^{x}$ & N1 & $108 \mathrm{~b}$ \\
\hline & SDI & $135 \mathrm{a}$ & N2 & $138 \mathrm{a}$ \\
\hline & & & N3 & $135 \mathrm{a}$ \\
\hline \multicolumn{5}{|l|}{2015} \\
\hline & DI & $141 \mathrm{~b}$ & N1 & $127 \mathrm{a}$ \\
\hline & SDI & $154 \mathrm{a}$ & N2 & $159 \mathrm{a}$ \\
\hline & & & N3 & $156 \mathrm{a}$ \\
\hline
\end{tabular}

z DI = drip irrigation, SDI = subsurface irrigation. ${ }^{\mathrm{y}} \mathrm{N} 1=(52-70 \mathrm{~kg} / \mathrm{ha}$ in $2012-2013), \mathrm{N} 2=(165-166 \mathrm{~kg} / \mathrm{ha})$ and N3 $=(245-279 \mathrm{~kg} / \mathrm{ha}) .{ }^{\mathrm{x}}$ Means followed by the same letter between treatments (i.e., irrigation system or N treatment) for each year were not significantly different at $p<0.05$. 
The total $\mathrm{N}$ uptake by fruit included both prime and subprime fruit. Prime fruit were defined as fruit with good color, greater than $8 \mathrm{~cm}$ diameter, with no visible cracks, and marketable as fresh fruit. Subprime fruit were those suitable for juicing and contained green and open-cracked fruits. Ayars et al. [17] evaluated treatment effects on total fruit yield and also prime and subprime fruit yield data (2013-2015). They found no statistical differences in yield between irrigation methods or $\mathrm{N}$ treatments, nor were there interactions on total yield, although there were some statistical differences in the prime and subprime fruits; thus, they concluded that $\mathrm{N} 1$ provided the $\mathrm{N}$ requirement, but our data presented in Table 4 showed that the N2 rate (application of 166-263 kg N/ha from 2013-2015) resulted in greater $\mathrm{N}$ uptake in fruit, leading us to conclude that the $\mathrm{N} 2$ rate provided sufficient $\mathrm{N}$ for tree growth and yield. Since all fruit were removed at harvest, the total $\mathrm{N}$ removed from the orchard by harvest should be used in N management, and the TN uptake data clearly showed effects from both irrigation and $\mathrm{N}$ application levels.

Additionally, a higher $\mathrm{N}$ application rate (N3) was excessive because there are no differences in total $\mathrm{N}$ uptake or yield (Ayars et al. [17]) compared with $\mathrm{N} 2$ treatment (Table 4). The total $\mathrm{N}$ uptake by fruit was $62 \%$ and $40 \%$ of total N applied for the N2 $(223 \mathrm{~kg} / \mathrm{ha})$ and N3 $(342 \mathrm{~kg} / \mathrm{ha})$ treatments, respectively, in 2014. Considering $\mathrm{N}$ storage in tree trunks and branches, the total $\mathrm{N}$ use efficiency was $>62 \%$ for N2, which is considered high in tree crops. Thus, the N2 rate (263 kg/ha applied in 2015) provided sufficient $\mathrm{N}$ for the trees. Similar results were also reported by Muhammad et al. [23], who found a positive effect of $\mathrm{N}$ rate in nut $\mathrm{N}$ uptake in mature almond orchards growing in well-drained Milham sandy loam soils (Typic Haplargids) in California, irrigated with a micro-sprinkler system and fertilized with four $\mathrm{N}$ treatments $(140,224,309$, and $392 \mathrm{~kg} / \mathrm{ha}$ ). For four years (2008-2011), the highest $\mathrm{N}$ uptake was observed from the $309 \mathrm{~kg} / \mathrm{ha}$ application rate.

\section{Conclusions}

This study evaluated the effect of DI versus SDI and three $\mathrm{N}$ application levels on $\mathrm{TN}, \mathrm{TC}, \mathrm{NO}_{3}{ }^{-}$, and DOC distribution in the soil as well as TN concentration or distribution in pomegranate tree tissues and total fruit $\mathrm{N}$ uptake in a fully irrigated orchard. The different irrigation designs resulted in very different $\mathrm{C}$ and $\mathrm{N}$ distributions in the soil profile. DI resulted in higher concentrations of $\mathrm{TN}, \mathrm{TC}, \mathrm{NO}_{3}{ }^{-}$, and DOC in soil depths above $75 \mathrm{~cm}$ compared with SDI, which resulted in higher concentrations in soil depths below $30 \mathrm{~cm}$. This was attributed to the placement of drip tubing at $\sim 50 \mathrm{~cm}$ soil depth in the SDI treatment. Higher TC and DOC in DI irrigation versus SDI can be attributed to a higher presence of weeds and tree growth over time, which contributed to generally increased surface soil OC. Overall data from soil analyses indicated that the N3 rate appeared to be excessive, with no yield increase, although it did increase the concentration of $\mathrm{TN}, \mathrm{TC}, \mathrm{NO}_{3}{ }^{-}$, and DOC in deep soils under both DI and SDI, indicating an increased leaching risk that must be avoided. Furthermore, the plant data indicated lower N utilization in N3 than N2. At or below the N2 (166-263 kg/ha for 4-6 year old pomegranate trees) application rate, high-frequency SDI showed no increased leaching risk compared to DI. The results indicate that a high-frequency irrigation method with proper $\mathrm{N}$ application rate could be managed to achieve high yield or high $\mathrm{N}$ uptake while reducing chemical input and leaching loss. Based on fruit $\mathrm{N}$ uptake, the $\mathrm{N} 2$ application rate was sufficient to meet maximum pomegranate tree $\mathrm{N}$ requirement. High-frequency SDI is an efficient system that can be recommended to San Joaquin Valley pomegranate farmers to save water, increase $\mathrm{N}$ uptake, and reduce leaching loss to protect groundwater quality.

Author Contributions: R.T.-C. and S.G. run the statistical analysis of the different measured variables and R.T.-C. and S.G. wrote the manuscript. J.E.A., C.J.P., D.W., and R.C.P. experiment logistic. All the authors revised the manuscript.

Funding: This research received no external funding.

Acknowledgments: We acknowledge California Department of Food and Agriculture (CDFA) for supplemental funding, KARE Center for the field site, and the following companies for contributions to this project: Paramount Farming—-trees and cones, Toro Irrigation—drip tubing, Lakos Filtration—sand media, Dorot—electronic control 
valves, Verdegaal Brothers-fertilizers, and SDI+-consulting time and miscellaneous equipment. In addition, the authors would like to thank Rick Schoneman for his assistance with the irrigation and fertigation systems. Also, we would like to thank Aileen Hendratna, Ryan Lancaster, Don Tucker, Matthew Gonzalez, Julianne Anaya, and Phyllis Ukatu for helping in the collection, preparation, and analysis of soil and plant samples at the San Joaquin Valley Agricultural Science Center, USDA-ARS-WMRU in Parlier, CA. In memory of Donald J. Makus, who helped us with pomegranate yield collection and analysis.

Conflicts of Interest: The authors declare no conflict of interest.

\section{References}

1. Yuan, Z.H.; Wilkins, E.; Wang, W. Proceedings of the Third International Symposium on Pomegranate and Minor Mediterranean Fruits; International Society of Horticultural Science: Leuven, Belgium, 2015; p. 493.

2. Wang, D.; Ayars, J.E.; Tirado-Corbalá, R.; Makus, D.; Phene, C.J.; Phene, R. Water and Nitrogen Management of Young and Maturing Pomegranate Trees. Acta Hort. 2015, 1089, 395-401. Available online: http: //www.actahort.org/books/1089/1089_53.htm (accessed on 3 August 2019). [CrossRef]

3. Gao, S.; Hendrata, A.; Zejiang, C.; Yinghua, D.; Qin, R.; Tirado-Corbalá, R. Subsurface Drip Irrigation Reduced Nitrous Oxide Emissions in Pomegranate Orchard. Int. J. Environ. Sci. Dev. 2019, 10, 79-85. [CrossRef]

4. California Department of Food and Agriculture (CDFA). Agricultural Statistics Review; CDFA: Sacramento, CA, USA, 2017.

5. Day, K.R.; Wilkins, E.D. Commercial Pomegranate (Punica granatum L.) production in California. In Proceedings of the IInd International Symposium on Pomegranate and Minor, including Mediterranean Fruits (ISPMMF-2009), Dharwar, India, 23-27 June 2009; Sheikh, M.K., Mokashi, A.N., Rokhade, A.K., Eds.; ISHS: Leuven, Belgium, 2011.

6. Holland, D.; Hatib, K.; Bar-Yaakov, I. Pomegranate: Botany, horticulture and breeding. Hortic. Rev. 2009, 35, 127-191.

7. Intrigliolo, D.S.; Nicolas, E.; Bonet, L.; Ferrer, P.; Alarcón, J.J.; Bartual, J. Water relations of field grown Pomegranate trees (Punica granatum) under different drip irrigation regimes. Agric. Water Manag. 2011, 98, 691-696. [CrossRef]

8. Ayars, J.E. Adapting Irrigated Agriculture to Drought in the San Joaquin Valley of California. In Drought in Arid and Semi-Arid Regions: A Multi-Disciplinary and Cross-Country Perspective; Springer: New York, NY, USA, 2013; pp. 25-39. [CrossRef]

9. Scudiero, E.; Skaggs, T.H.; Corwin, D.L. Regional scale soil salinity evaluation using Landsat 7, western San Joaquin Valley, California, USA. Geoderma Reg. 2014, 2, 82-90. [CrossRef]

10. Mertens-Talcott, S.U.; Jilma-Stohlawetz, P.; Rios, J.; Hingorani, L.; Derenorf, H. Absorption, metabolism, and antioxidant effects of Pomegranate (Punica granatum L.) polyphenols after ingestion of a standardized extract in healthy human volunteers. J. Agric. Food Chem. 2006, 54, 8956-8961. [CrossRef] [PubMed]

11. Galindo, A.; Calín-Sánchez, Á.; Collado-González, J.; Odoño, S.; Hernández, F.; Torrecillas, A.; Carbonell-Barrachina, Á.A. Phytochemical and quality attributes of pomegranate fruits for juice consumption as affect by ripening stage and deficit irrigation. J. Sci. Food Agric. 2014, 94, 2259-2265. [CrossRef]

12. Chauhan, S.K. Pomegranate grown in drip and furrow irrigation system in saline water condition of semi-arid areas. Technofame 2013, 2, 124-126.

13. Glozer, K.; Ferguson, L. Pomegranate production in Afghanistan. UCDAVIS Coll. Agric. Environ. Sci. 2008, 32, 1-32.

14. Parvizi, H.; Sepaskhah, A.R.; Ahmadi, S.H. Effect of drip irrigation and fertilizer regimes on fruit yields and water productivity of a pomegranate (Punica granatum (L.) cv. Rabab) orchard. Agric. Water Manag. 2014, 146, 45-56. [CrossRef]

15. Parvizi, H.; Sepaskhah, A.R.; Ahmadi, S.H. Physiological and growth responses of pomegranate tree (Punica granatum (L.) cv. Rabab) under partial root zone drying and deficit irrigation regimes. Agric. Water Manag. 2016, 163, 146-158. [CrossRef]

16. Parvizi, H.; Sepaskhah, A.R. Effect of drip irrigation and fertilizer regimes on fruit quality of a pomegranate (Punica granatum (L.) cv. Rabab) orchard. Agric. Water Manag. 2015, 156, 70-78. [CrossRef]

17. Ayars, J.E.; Phene, C.J.; Phene, R.C.; Gao, S.; Wang, D.; Day, K.R.; Makus, D.J. Determining Pomegranate Water and Nitrogen Requirements with Drip Irrigation. Agric. Water Manag. 2017, 187, 11-23. [CrossRef] 
18. Anderson, R.G.; Lo, M.H.; Famiglietti, J.M. Assessing surface water consumption using remotely-sensed groundwater, evapotranspiration, and precipitation. Geophys. Res. Lett. 2012, 39, L16401. [CrossRef]

19. Chapelle, F.H.; Campbell, B.G.; Widowson, M.A.; Landon, M.K. Modeling the long-term fate of agricultural nitrate in groundwater in the San Joaquin Valley, California. In Current Perspectives in Contaminant Hydrology and Water Resources Sustainability; Paul, B., Ed.; IntechOpen: Rijeka, Croatia, 2013. [CrossRef]

20. Harter, T.; Onsoy, Y.S.; Heeren, K.; Denton, M.; Weismann, G.; Hopmans, J.W.; Horwath, W.R. Deep vadose zone hydrology demonstrates fate of nitrate in eastern San Joaquin Valley. Calif. Agric. 2005, 59, 124-132. [CrossRef]

21. Harter, T.; Lund, J.R.; Darby, J. Addressing nitrate in California's drinking water with focus on Tulare Lake Basin and Salinas Valley groundwater. In Report for the State Water Resources Control Board Report to the Legislature; Center for Watershed Sciences, UC Davis, CA: Yolo County, CA, USA, 2012; p. 78.

22. Jurgens, B.C.; Burow, K.R.; Dalgish, B.A.; Shelton, J.L. Hydrogeology, Water Chemistry, and Factors Affecting the Transport of Contaminants in the Zone of Contribution of Public-Supply Well in Modesto, Eastern San Joaquin Valley, California; U.S. Geological Survey: Reston, WV, USA, 2008; Volume 5156, p. 78.

23. Muhammad, S.; Sanden, B.L.; Lampinen, B.D.; Saa, S.; Siddiqui, M.I.; Smart, D.R.; Olivos, A.; Shackel, K.A.; DeJong, T.; Brown, P.H.; et al. Seasonal changes in nutrient content and concentrations in a mature deciduous tree species: Studies in almond (Prunus dulcis (Mill.) D.A. Webb). Eur. J. Agron. 2015, 65, 52-68. [CrossRef]

24. Chomycia, J.C.; Hernes, P.J.; Harter, T.; Bergamaschi, B.A. Land management impacts on dairy-derived dissolved organic carbon in ground water. J. Environ. Qual. 2008, 37, 333-343. [CrossRef]

25. Viers, J.H.; Liptzin, D.; Rosenstock, T.S.; Jensen, V.B.; Hollander, A.D.; McNally, A.D.; King, A.; Kourakos, A.M.; Lopez, G.; De La Mora, E.M.; et al. Nitrogen sources and loading to groundwater. Technical report 2. In Addressing Nitrate in California's Drinking Water Resources Control Board Report to the Legislature; Center for Watershed Sciences, University of California: Davis, CA, USA, 2012.

26. Ayars, J.E.; Phene, C.J.; Hutmacher, R.B.; Davis, K.R.; Schoneman, R.A.; Vail, S.S.; Mead, R.M. Subsurface drip irrigation of row crops: A review of 15 years of research at the Water Management Research Laboratory. Agric. Water Manag. 1999, 42, 1-27. [CrossRef]

27. Baram, S.; Couvreur, V.; Harter, T.; Read, M.; Brown, P.H.; Kandelous, M.; Smart Hopmans, J.W. Estimating nitrate leaching to groundwater from orchards: Comparing crop nitrogen excess, deep vadose zone data-driven estimates, and HYDRUS modeling. Vadose Zone J. 2016, 15, 11. [CrossRef]

28. Phene, C.J.; Ayars, J.E.; Phene, R.C.; Schoneman, R.S. Irrigation and fertigation with high frequency subsurface drip irrigation can prevent drainage and groundwater contamination. In Proceedings of the 2015 ASABE/IA Irrigation Symposium: Emerging Technologies for Sustainable Irrigation-A Tribute to the Career of Terry Howell, Sr. Conference Proceedings, Long Beach, CA, USA, 10-12 November 2015.

29. Zhang, H.; Wang, D.; Ayars, J.E.; Phene, C.J. Biophysical response of young pomegranate tree to surface and sub-surface drip irrigation and deficit irrigation. Irrig. Sci. 2017, 35, 425-435. [CrossRef]

30. Phene, C.J.; Hoffman, G.J.; Howell, T.A.; Clark, D.A.; Mead, R.M.; Johnson, R.S.; Williams, L.E. Automated Lysimeter for Irrigation and Drainage Control. Lysimeters for Evapotranspiration and Environmental Measurements; ASCE: New York, NY, USA, 1991.

31. Ayars, J.E.; Johnson, R.S.; Phene, C.J.; Trout, T.J.; Clark, D.A.; Mead, R.M. Crop water use by late season drip irrigated peaches. Irrig. Sci. 2003, 22, 187-194. [CrossRef]

32. De Ferreira, E.V.O.; Novais, R.F.; Médice, B.M.; de Barros, N.F.; Silva, I.R. Leaf total nitrogen concentration as an indicator of nitrogen status for plantlets and young plants of eucalyptus clones. Revista Brasileira de Ciência do Solo 2015, 39, 1127-1140. [CrossRef]

33. Decock, C.; Garland, G.; Suddick, C.E.; Six, J. Season and location-specific nitrous oxide emissions in an almond orchard in California. Nutr. Cycl. Agroecosyst. 2017, 107, 139-155. [CrossRef]

34. Wolf, K.; Herrera, I.; Tomich, T.; Scow, K. Long-term agricultural experiments inform the development of climate-smart agricultural practices. Calif. Agric. 2017, 71, 120-124. [CrossRef]

35. Ge, S.; Xu, H.; Ji, M.; Jiang, y. Characteristics of Soil Organic Carbon, Total Nitrogen, and C/N Ratio in Chinese Apple Orchards. Open J. Soil Sci. 2015, 3, 213-217. [CrossRef]

36. Bangroo, S.; Itoo, H.; Tasneem, M.; Malik, A.R. Soil organic carbon and total nitrogen in temperate apple orchards of south Kashmir. Int. J. Ecol. Environ. Sci. 2018, 44, 287-292. Available online: https://file.scirp.org/Html/2-1660139_36404.htm (accessed on 3 August 2019). 
37. Gullickson, G. Here's Why the Carbon-Nitrogen Ratio Matters. Available online: https://www.agriculture. com/crops/cover-crops/heres-why-carbonnitrogen-ratio-matters_568-ar48014 (accessed on 3 August 2019).

38. Diacono, M.; Montemurro, F. Long-term effects of organic amendments on soil fertility. A review. Agron. Sustain. Dev. 2010, 30, 401-422. [CrossRef]

39. Chen, J.; Luo, Y.; van Groenigen, K.J.; Hungate, B.A.; Cao, J.; Zhou, X.; Wang, R.W. A keystone microbial enzyme for nitrogen control of soil carbon storage. Sci. Adv. 2018, 4, eaaq1689. [CrossRef]

40. Jian, S.; Li, J.; Chen, J.; Wang, G.; Mayes, M.; Dzantor, K.; Hui, D. Soil extracellular enzyme activities, soil carbon and nitrogen storage under nitrogen fertilization: A meta-analysis. Soil Biol. Biochem. 2016, 101, 32-43. [CrossRef]

41. Luo, Y.; Chen, J.; Chen, Y.; Feng, W. Data-driven microbial modeling for soil carbon decomposition and stabilization. In Proceedings of the EGU General Assembly Conference Abstracts, Vienna, Austria, 23-28 April 2017; Available online: https://meetingorganizer.copernicus.org/EGU2017/EGU2017-4548.pdf (accessed on 3 August 2019).

42. Gong, S.; Guo, R.; Zhang TGuo, J. Warming and nitrogen addition increase litter decomposition in a temperate meadow ecosystem. PLoS ONE 2015, 10, e0116013. [CrossRef]

43. Talbot, J.M.; Treseder, K.K. Interactions among lignin, cellulose, and nitrogen drive litter chemistry-decay relationships. Ecology 2012, 93, 345-354. [CrossRef] [PubMed]

44. Gu, C.; Liu, Y.; Mohamed, I.; Zhang, R.; Wang, X.; Nie, X.; Jiang, M.; Brooks, M.; Chen, F.; Li, Z. Dynamic Changes of Soil Surface Organic Carbon under Different Mulching Practices in Citrus Orchards on Sloping Land. PLoS ONE 2016, 11, e0168384. [CrossRef] [PubMed]

45. Sebastian, S.; Muhammad, S.; Brown, P.H. Development of Leaf Sampling and Interpretation Methods and Nutrient Budget Approach to Nutrient Management in Almond (Prunus dulcis (Mill.) D.A. Webb). Acta Hortic. 2013, 984, 291-296. [CrossRef]

(C) 2019 by the authors. Licensee MDPI, Basel, Switzerland. This article is an open access article distributed under the terms and conditions of the Creative Commons Attribution (CC BY) license (http://creativecommons.org/licenses/by/4.0/). 